\title{
Phytochemicals and Volatiles in Developing Pelargonium 'Endsleigh' Flowers
}

\author{
Carmine Negro ${ }^{1}\left(\mathbb{0}\right.$, Rosanna Dimita $^{1}$, Samar Min Allah ${ }^{1}$, Antonio Miceli ${ }^{1}$, Andrea Luvisi ${ }^{1}{ }^{(0}$, Federica Blando ${ }^{2}{ }^{(0)}$, \\ Luigi De Bellis ${ }^{1}$ (D) and Rita Accogli 1,*(D) \\ 1 Department of Biological and Environmental Science and Technologies (DiSTeBA), University of Salento, \\ Via Prov. le Lecce-Monteroni, 73100 Lecce, Italy; carmine.negro@unisalento.it (C.N.); \\ rosanna.dimita@unisalento.it (R.D.); samar.minallah@unisalento.it (S.M.A.); \\ antonio.miceli@unisalento.it (A.M.); andrea.luvisi@unisalento.it (A.L.); luigi.debellis@unisalento.it (L.D.B.) \\ 2 Institute of Sciences of Food Production, CNR, Via Prov. le Lecce-Monteroni, 73100 Lecce, Italy; \\ federica.blando@ispa.cnr.it \\ * Correspondence: rita.accogli@unisalento.it
}

Citation: Negro, C.; Dimita, R.; Min Allah, S.; Miceli, A.; Luvisi, A.; Blando, F.; De Bellis, L.; Accogli, R. Phytochemicals and Volatiles in Developing Pelargonium 'Endsleigh' Flowers. Horticulturae 2021, 7, 419. https://doi.org/10.3390/ horticulturae7110419

Received: 24 September 2021 Accepted: 18 October 2021 Published: 20 October 2021

Publisher's Note: MDPI stays neutral with regard to jurisdictional claims in published maps and institutional affiliations.

Copyright: (c) 2021 by the authors. Licensee MDPI, Basel, Switzerland. This article is an open access article distributed under the terms and conditions of the Creative Commons Attribution (CC BY) license (https:// creativecommons.org/licenses/by/ $4.0 /)$.

\begin{abstract}
Rose-scented geranium (Pelargonium sp.) have been the subject of many studies concerning essential oil, unlike the edible flowers of scent Pelargonium despite the beneficial properties of chemical compounds present in such organ and the fragrances produced. Therefore, we investigated organic compounds, total phenols and the antioxidant activity of the flowers with particular attention to the volatile compounds emitted by flowers of Pelargonium 'Endsleigh' at three stages of development. We identified several major phenols and organic compounds that revealed significative difference compared with other Pelargonium flowers, and employing the solid-phase micro extraction (SPME) methodology we determined that the production of volatile compounds decreases during the flower development. In addition, the emission of volatiles is accomplished mainly by the sepals. In conclusion, to use Pelargonium 'Endsleigh' flowers, it is important in ensuring that they have not yet opened and that the sepals are in place.
\end{abstract}

Keywords: volatile organic compounds (VOCs); phenols; flower antioxidant activity; floral scent

\section{Introduction}

Flowers are the reproductive organs of angiosperms and have the task of facilitating sexual reproduction. To attract pollinators, they produce bright colours and volatile compounds together with abundant pollen and nectar, which are the reward for pollinators attracted by the colours and fragrant compounds. However, florivores are also attracted, and in some cases discouraged by the emission of particular combinations of volatile compounds [1].

In addition, it is an ancient custom to use flowers as food, a tradition that has recently gained new considerable popularity not only because of the particular taste and smell but also because of the beneficial components for human health present [2]; confirming this a paper by Demasi et al. [3] on the conservation of edible flowers was chosen as the cover story of the July 2021 issue of Horticulturae.

The species of the genus Pelargonium are most famous for the essential oils extracted from their fragrant leaves and for their ornamental value. The interest in Pelargonium plants is due to their varied and intense scents including rose, nutmeg, green apple, coconut, almond, lemon, peppermint and strawberry. 'Scented Pelargonium' (historically scented geraniums) indicates a group of aromatic plants in which the leaves and flowers have many uses in recipes, aromatherapy, herbal and medicinal preparations [4-6].

Pelargonium flowers are little studied although some of them, e.g., flowers of $P$. graveolens, P. tomentosum, P. odoratissium and P. fragrans are included in various recipes, especially sweet ones, and are marketed as edible flowers [7]. The Pelargonium cultivar 
'Endsleigh' (lavender scented) has long been considered a variety originating from a cross between Pelargonium capitatum (hexaploid $2 \mathrm{n}=66$ ) and Pelargonium quercifolium (tetraploid $2 n=44)$ [8]. This plant has strongly scented spicy leaves which can be used to add a mixed spice flavour to cooking and makes a great long-lasting potpourri [9].

Plant volatile organic compounds (VOCs) are involved in essential biological functions such as defence against herbivorous predators and pathogens, attraction of pollinating insects and seed dispersal [10] while some components determine aromatic characteristics which are employed to add flavour to food playing an important role in the acceptability of products by consumers [11].

Therefore, we decided to study the VOCs produced by the flowers of Pelargonium 'Endsleigh' during the flowering process (mature bud, full bloom, senescing) by the whole flower and its parts (sepals, petals, stamens and carpels) in order to identify the chemical compounds produced and which part of the flower is most active in the production of VOCs. In addition, both the phytochemical profile and the antioxidant activity of the flowers were examined.

\section{Materials and Methods}

Fresh Pelargonium 'Endsleigh' flowers were harvested at three stages of development: mature bud, full bloom and senescing (Figure 1) and analysed as such or after separation into sepals, petals and stamens/pistils (Figure 2). The dry weight was determined by placing the flowers in an oven at a temperature of $105^{\circ} \mathrm{C}$ to constant weight.

The analysis of volatile compounds was carried out by solid-phase micro extraction (SPME) methodology. Approximately $1 \mathrm{~g}$ (FW) of flowers was sealed into 20-mL SPME vials (Agilent Technologies, Palo Alto, CA, USA) by metal screw-caps with pre-notched Teflon silicone septa. The vials were then placed at $40{ }^{\circ} \mathrm{C}$ for $5 \mathrm{~min}$ in a thermostatically controlled bath to allow the evaporation of the compounds; hereafter, a SPME syringe was inserted and the fibre (50/30 $\mu \mathrm{m}$ Divinylbenzene/Carboxen/Polydimethylsiloxane, Supelco/Merck KGaA, Darmstadt, Germany), which was previously conditioned for $5 \mathrm{~min}$ at $235{ }^{\circ} \mathrm{C}$ in the gas chromatograph injector, was exposed for $10 \mathrm{~min}$ to absorb the volatile compounds. Subsequently, the fibre was inserted into the injector port of a gas chromatography with a mass spectrometry detector (Agilent 7890B coupled with MS single quadripole Agilent 5977A) and the desorption of the volatile compounds was performed at $235^{\circ} \mathrm{C}$ for $4 \mathrm{~min}$. The injector was operated under spitless mode. At this point, the chromatographic run was started with an Agilent HP-5ms column $(30 \mathrm{~m} \times 0.25 \mathrm{~mm}$, $0.25 \mu \mathrm{m}$ ) (which temperature was raised from $60^{\circ} \mathrm{C}$ to $250{ }^{\circ} \mathrm{C}$ with a constant increase of $3{ }^{\circ} \mathrm{C} / \mathrm{min}$ ) with a constant helium (purity $>99.999 \%$ ) flow of $1.0 \mathrm{~mL} / \mathrm{min}$. Compounds were identified by library search and/or analytical standard if available. The mass spectrum of an unknown compound was searched in data processing system [12]. Substances with a score above 800 , both in terms of identity and purity, were considered to be identified after comparing the detected compound with the one in the NIST Computational Chemistry Comparison and Benchmark database [12]. Retention index (RI) was obtained essentially as reported by Zhao et al. [13] employing as reference the retention times of a series of $\mathrm{C}_{8}-\mathrm{C}_{20}$ alkanes separated under the GC-MS conditions mentioned above, and applying the following formula:

$$
\mathrm{RI}=100 \times n+\frac{100\left(t_{a}-t_{n}\right)}{t_{n+1}-t_{n}}
$$

where, $t_{a}$ is the retention time of the unknown peak $a ; t_{n}$ the retention time of $n$-alkane $C n$; and $t_{n+1}$ the retention time of $n$-alkane $C_{n+1} ; n=$ carbon number of the alkane which elutes before the unknown peak $a$.

The semi-quantitative analysis of volatile compounds was carried out as reported by Zhao et al. [13] with some modifications. The compound 1,7,7-trimethylbiciclo [2.2.1] 2-heptanone was chosen as the internal standard; $2 \mu \mathrm{L}$ of a solution $1.25 \mu \mathrm{g} / \mathrm{mL}$ of internal standard in hexane were added to the samples. The calculation of the amount of VOCs was determined with the following formula: $\mathrm{Qc}=(\mathrm{Qs} \times \mathrm{Ac}) / \mathrm{As}$ where $\mathrm{Qc}$ is the amount 
of VOC in the sample, Qs the amount of standard, Ac the area of the VOC in the sample and As the area of the standard.

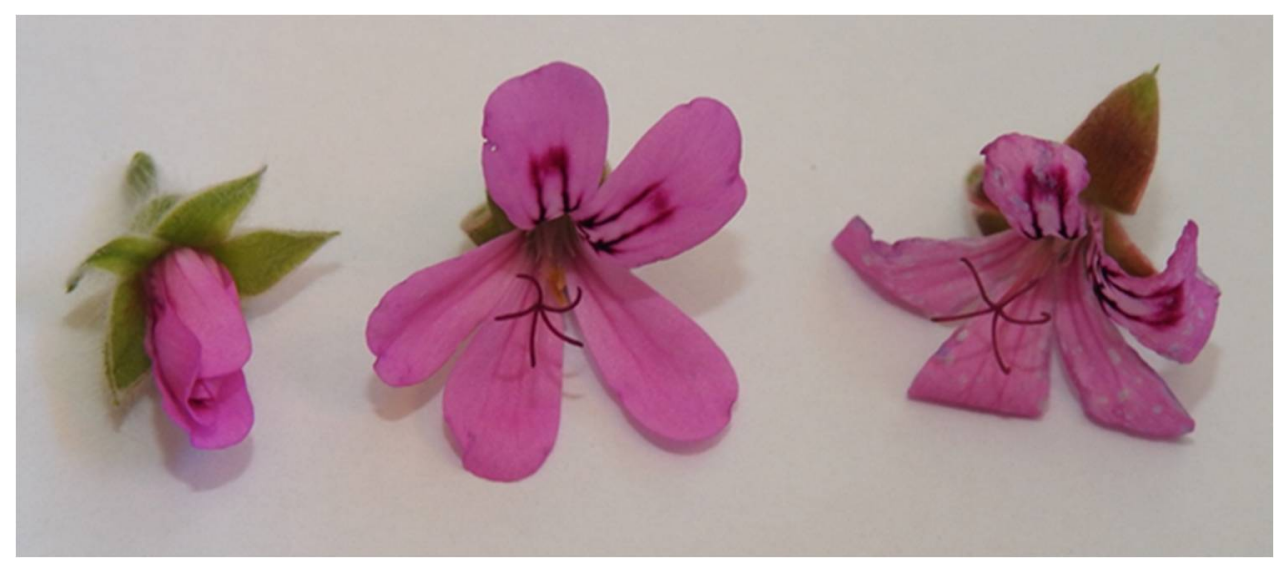

Figure 1. Flowers of $P$. 'Endsleigh' at three flowering stages: mature bud, full bloom and senescing.
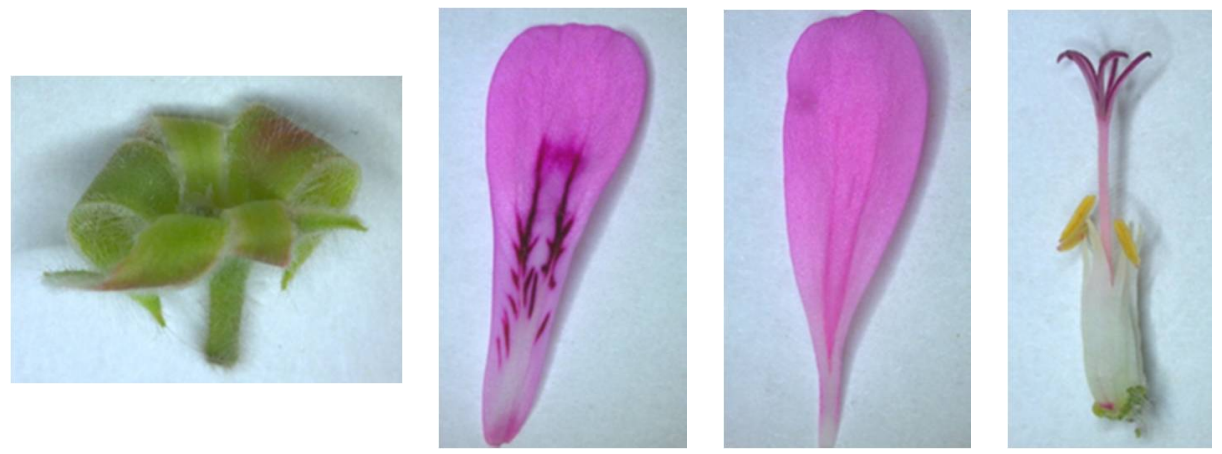

Figure 2. Sepals, petals and stamens/pistils of the flower of $P$. 'Endsleigh' at full bloom stage.

Phenolic and organic compound characterization. Samples finely powdered with mortar and pestle in presence of liquid nitrogen were extracted in a ratio of 1:20 FW/V with methanol:water (75:25) acidified with formic acid $0.1 \%$ for $30 \mathrm{~min}$ in constant agitation. The extract was centrifuged, and the extraction was repeated on the pellet. The supernatants were mixed and evaporated, then resuspended with high performance liquid chromatography (HPLC) water acidified with $0.1 \%$ formic acid.

The total phenolic content (TPC) was determined using the spectrophotometric FolinCiocalteau method [14], the absorbance was measured after a 1:10 dilution with a JASCO V-550 UV/VIS spectrophotometer at $765 \mathrm{~nm}$, and data were expressed as $\mathrm{mg}$ of gallic acid equivalent (GAE) per g dry weight (DW).

Compound characterization was performed by an Agilent 1200 Liquid Chromatography system (Agilent Technologies, Palo Alto, CA, USA) equipped with a standard autosampler. The HPLC column was an Agilent Extended C18 $(1.8 \mu \mathrm{m}, 2.1 \times 50 \mathrm{~mm})$. Separation was carried out at $40{ }^{\circ} \mathrm{C}$ with a gradient elution program at a flowrate of $0.5 \mathrm{~mL} / \mathrm{min}$. The mobile phases consisted of water plus $0.1 \%$ formic acid (A) and acetonitrile (B). The following multistep linear gradient was applied: $0 \mathrm{~min}, 5 \% \mathrm{~B} ; 13 \mathrm{~min}, 25 \% \mathrm{~B}$; $19 \mathrm{~min}, 40 \% \mathrm{~B}$. The injection volume in the HPLC system was $5 \mu \mathrm{L}$. The HPLC system was coupled to a DAD (Agilent Technologies) set at $280 \mathrm{~nm}$ and an Agilent $6320 \mathrm{TOF}$ mass spectrometer equipped with a dual electrospray ionization (ESI) inter-face (Agilent Technologies) operating in negative ion mode. Detection was carried out within a mass range of 50-1700 m/z. Accurate measurements of the mass corresponding to each total ionic current (TIC) peak were obtained with a pump (Agilent G1310B) introducing a low flow $(20 \mu \mathrm{L} / \mathrm{min})$ of a calibration solution containing internal reference masses at $\mathrm{m} / \mathrm{z}$ 
112.9856, 301.9981, 601.9790, 1033.9881, and using a dual nebulizer ESI source in negative ion mode [15]. Other mass spectrometer conditions were as follows: capillary voltage $3.0 \mathrm{kV}$ in negative mode; nitrogen was used as the nebulizer and desolvation gas; drying gas temperature: $300{ }^{\circ} \mathrm{C}$; drying gas flow: $12 \mathrm{~L} / \mathrm{min}$, nebulizing gas pressure: 40 psig; finally, the source temperature was $120^{\circ} \mathrm{C}$. Mass Hunter software (Agilent Technologies, Palo Alto, CA, USA) was used to process the mass data of the molecular ions.

The compounds were quantified using calibration curves of authentic standards myricetin, kaempferol, quercetin purchase from Merck Life Science (Milano, Italy), while Myricetin 3-O-glucoside, Kaempferol 3-O-galactoside and Kaempferol 3-O-glucoside were employed for the identification of chemical compounds after HPLC/MS analysis.

The evaluation of the antioxidant activity was carried out by testing three aspects: scavenger, reducing and quenching capacity.

DPPH Assay. Antioxidant activity was determined in vitro by evaluation of the free radical scavenging activity using 2,2-diphenyl-1-picrylhydrazyl (DPPH•) (DPPH assay) [16]. Inhibition of free radical DPPH• was expressed as Trolox (6-hydroxy-2,5,7,8tetra-methylchroman-2-carboxylic acid) equivalents (TE) per g DW.

Ferric Reducing Antioxidant Power (FRAP). The ferric reducing ability was determined by the FRAP method [17]. The absorption of the reaction mixture was measured at $593 \mathrm{~nm}$ using Perkin Elmer 2030 Multilabel reader Victor X5 after 3 min of incubation at $37^{\circ} \mathrm{C}$. The samples were measured in triplicate, and the FRAP was expressed as Trolox equivalents (TE)/g DW.

Superoxide anion scavenging activity assay. The assay was carried out according to Beauchamp and Fridovich [18]. The photo-induced reactions were performed using fluorescent lamps (200 W at $1 \mathrm{~m}$ ). All samples were measured in triplicate, and the superoxide anion scavenging activity was expressed as g DW corresponding to half maximal inhibitory concentration $\left(\mathrm{IC}_{50}\right)$.

All data were reported as the mean \pm standard deviation (SD), with at least three replications for each sample. Statistical evaluation was conducted by Duncan's test to discriminate among the mean values. All statistical analyses were performed using the software Statistica (StatSoft, Tulsa, OK, USA).

\section{Results}

\subsection{Phenols and Organic Compounds in P. 'Endsleigh' Flowers}

The compounds most commonly present in the floral tissues at the three flowering stages are shown in Table 1 and Figure S1. There are some organic acids, such as tartaric and malic, and phenolic acids derived such as Monogalloylhexose and Methylated protocatechuic acid hexose. Flavonoids such as Myricetin 3-O-glucoside, Kaempferol 3-O-di-p-coumaroylhexoside and Quercetin 3-O-pentoside are also included.

Table 1. Major constituents identified by HPLC/MS in tissues of $P$. 'Endsleigh' flowers at three developmental stages.

\begin{tabular}{|c|c|c|c|c|c|c|c|}
\hline No & Formula $[\mathrm{M}-\mathrm{H}]^{-}$ & $m / z \operatorname{Exp}$ & $m / z$ Calc & Error ppm & Score & Compound Name & Refs. \\
\hline 1 & $\mathrm{C}_{4} \mathrm{H}_{5} \mathrm{O}_{6}$ & 149.0072 & 149.0092 & 13.31 & 78 & * Tartaric acid & {$[19,20]$} \\
\hline 2 & $\mathrm{C}_{4} \mathrm{H}_{6} \mathrm{O}_{5}$ & 133.0120 & 133.0142 & 17.27 & 76 & ${ }^{*}$ Malic acid & [21] \\
\hline 3 & $\mathrm{C}_{13} \mathrm{H}_{15} \mathrm{O}_{10}$ & 331.0714 & 331.067 & -13.3 & 79 & Monogalloylhexose & [22] \\
\hline 4 & $\mathrm{C}_{4} \mathrm{H}_{8} \mathrm{O}_{5}$ & 135.0292 & 135.0299 & 5.05 & 85 & unknow & - \\
\hline 5 & $\mathrm{C}_{17} \mathrm{H}_{15} \mathrm{O}_{7}$ & 331.0795 & 331.0823 & 8.66 & 80 & unknow & - \\
\hline 6 & $\mathrm{C}_{14} \mathrm{H}_{18} \mathrm{O}_{9}$ & 329.0910 & 329.0878 & -9.72 & 75 & Methylated protocatechuic acid hexose & [23] \\
\hline 7 & $\mathrm{C}_{25} \mathrm{H}_{22} \mathrm{O}_{8}$ & 449.123 & 449.1242 & 2.62 & 81 & Flavanone hexoside & [23] \\
\hline 8 & $\mathrm{C}_{23} \mathrm{H}_{34} \mathrm{O}_{17}$ & 581.1691 & 581.1723 & 5.59 & 79 & $\begin{array}{l}\text { Methyl syringate } 4-O-\beta \text {-d-gentiobiose } \\
\text { (Leptosperin) }\end{array}$ & [24] \\
\hline 9 & $\mathrm{C}_{24} \mathrm{H}_{17} \mathrm{O}_{9}$ & 479.0860 & 479.0831 & -6.05 & 75 & * Myricetin 3-O-glucoside & [23] \\
\hline 10 & $\mathrm{C}_{20} \mathrm{H}_{17} \mathrm{O}_{12}$ & 449.0856 & 449.0878 & 4.94 & 78 & unknow & - \\
\hline
\end{tabular}


Table 1. Cont

\begin{tabular}{|c|c|c|c|c|c|c|c|}
\hline No & Formula $[\mathrm{M}-\mathrm{H}]^{-}$ & $m / z \operatorname{Exp}$ & $m / z$ Calc & Error ppm & Score & Compound Name & Refs. \\
\hline 11 & $\mathrm{C}_{30} \mathrm{H}_{44} \mathrm{O}_{21}$ & 739.2288 & 739.2302 & 1.91 & 85 & Kaempferol 3-O-di- $p$-coumaroylhexoside & [25] \\
\hline 12 & $\mathrm{C}_{25} \mathrm{H}_{19} \mathrm{O}_{9}$ & 463.1032 & 463.1035 & 0.54 & 85 & Myricetin-3-O-rhamnoside & {$[26]$} \\
\hline 13 & $\mathrm{C}_{30} \mathrm{H}_{44} \mathrm{O}_{21}$ & 739.2286 & 739.2302 & 2.18 & 80 & Kaempferol 3-O-di-p-coumaroylhexoside & {$[25]$} \\
\hline 14 & $\mathrm{C}_{25} \mathrm{H}_{20} \mathrm{O}_{9}$ & 463.1033 & 463.1035 & 0.38 & 85 & Myricetin-3-O-rhamnoside is. II & [26] \\
\hline 15 & $\mathrm{C}_{31} \mathrm{H}_{30} \mathrm{O}_{12}$ & 593.1682 & 593.1664 & -3 & 79 & Proanthocyanidin & {$[27]$} \\
\hline 16 & $\mathrm{C}_{24} \mathrm{H}_{18} \mathrm{O}_{8}$ & 433.0919 & 433.0929 & 2.38 & 78 & Quercetin 3-O-pentoside & [23] \\
\hline 17 & $\mathrm{C}_{21} \mathrm{H}_{19} \mathrm{O}_{11}$ & 447.0949 & 447.0933 & -3.13 & 86 & * Kaempferol 3-O-galactoside & {$[23]$} \\
\hline 18 & $\mathrm{C}_{21} \mathrm{H}_{19} \mathrm{O}_{11}$ & 447.0962 & 447.0933 & -5.46 & 85 & * Kaempferol 3-O-glucoside & {$[23]$} \\
\hline 19 & $\mathrm{C}_{24} \mathrm{H}_{18} \mathrm{O}_{7}$ & 417.0954 & 417.0980 & 2.8 & 78 & Kaempferol 3-O-pentoside & {$[23]$} \\
\hline 20 & $\mathrm{C}_{22} \mathrm{H}_{16} \mathrm{O}_{5}$ & 359.0883 & 359.0925 & 3.8 & 79 & unknow & - \\
\hline
\end{tabular}

\subsection{Phenolic Content and Antioxidant Activity}

Table 2 presents the content of total phenolic compounds in developing $P$. 'Endsleigh' flowers; there is no significant difference between the three flowering stages. The average value is $31.4 \mathrm{mg} / \mathrm{g}$ FW corresponding to about $142 \mathrm{mg} / \mathrm{g}$ DW.

Table 2. Content of total phenolic compounds (TPC) at the three flowering stages of $P$. 'Endsleigh', expressed as mg GAE/g of fresh and of dry weight.

\begin{tabular}{ccc}
\hline \multirow{2}{*}{ Floral Development Stage } & \multicolumn{2}{c}{ TPC } \\
\cline { 2 - 3 } & mg GAE/g FW & mg GAE/g DW \\
\hline Mature bud & $33.9 \pm 1.5 \mathrm{a}$ & $154.2 \pm 6.8 \mathrm{a}$ \\
\hline Full bloom & $28.3 \pm 1.4 \mathrm{~b}$ & $128.0 \pm 6.7 \mathrm{~b}$ \\
\hline Senescing & $32.1 \pm 1.5 \mathrm{a}$ & $145.1 \pm 6.5 \mathrm{a}$ \\
\hline
\end{tabular}

In the same column, different letters correspond to statistically different means (Duncan's test, $n=3, p<0.05$ ).

Table 3 shows the levels of the main flavonoids in $P$. 'Endsleigh' flowers. The compound most present is Myricetin 3-O-hexoside, with average value of approximately $8 \mathrm{mg} / \mathrm{g}$ DW, and with an apparent slight increase towards the senescing stage; Kaempferol 3-O-di- $p$-coumaroyl-hexoside and Myricetin-3-O-rhamnoside showed similar values of about $6 \mathrm{mg} / \mathrm{g} \mathrm{DW}$, with the first compound dropping as the flowers develop and the second tending to grow slightly; Quercetin 3-O-pentoside is present in smaller quantities (approximately $4 \mathrm{mg} / \mathrm{g}$ DW) and gradually increases towards the senescence stage.

Table 3. Content of flavonoid compounds, in the three flowering stages of $P$. 'Endsleigh', expressed as mg/g of dry weight.

\begin{tabular}{ccccc}
\hline $\begin{array}{c}\text { Floral Development } \\
\text { Stage }\end{array}$ & $\begin{array}{c}\mathbf{1}^{\mathbf{1}} \text { Myricetin } \\
\text { 3-O-glucoside }\end{array}$ & $\begin{array}{c}{ }^{\mathbf{2}} \text { Kaempferol3-O-di-p- } \\
\text { coumaroyl-hexoside }\end{array}$ & $\begin{array}{c}{ }^{\mathbf{1}} \text { Myricetin-3-O- } \\
\text { rhamnoside }\end{array}$ & $\begin{array}{c}{ }^{\mathbf{3}} \text { Quercetin } \\
\text { 3-O-pentoside }\end{array}$ \\
\hline Mature bud & $7.4 \pm 0.5 \mathrm{a}$ & $7.8 \pm 0.3 \mathrm{a}$ & $6.0 \pm 0.3 \mathrm{~b}$ & $3.6 \pm 0.6 \mathrm{a}$ \\
\hline Full bloom & $8.1 \pm 0.8 \mathrm{a}$ & $6.2 \pm 0.4 \mathrm{~b}$ & $6.3 \pm 0.8 \mathrm{ab}$ & $3.8 \pm 0.9 \mathrm{a}$ \\
\hline Senescing & $8.7 \pm 0.7 \mathrm{a}$ & $5.1 \pm 0.5 \mathrm{~b}$ & $7.4 \pm 0.7 \mathrm{a}$ & $4.6 \pm 1.2 \mathrm{a}$ \\
\hline
\end{tabular}

${ }^{1}$ : Determined as Myricetin; ${ }^{2}$ : determined as Kaempferol; ${ }^{3}$ : determined as Quercetin. In the same column, different letters correspond to statistically different means (Duncan's test, $n=3, p<0.05$ ).

The antioxidant activity was evaluated by three different tests (DPPH, FRAP and superoxide anion scavenging activity assay) and expressed as Trolox equivalent (TE)/g DW or as g DW corresponding to $\mathrm{IC}_{50}$; data are reported in Table 4 . The full bloom stage flowering stage showed a higher antioxidant activity regardless of the type of test, although the total phenolic content is lower at this stage of development. 
Table 4. Antioxidant activity of the $P$. 'Endsleigh' flowers expressed as Trolox equivalent (TE $\mu \mathrm{mol} / \mathrm{g} \mathrm{DW}$ ) for DPPH and FRAP, and as $\mathrm{IC}_{50}$ (g DW) for the superoxide anion scavenging activity assay.

\begin{tabular}{lccc}
\hline $\begin{array}{c}\text { Floral Development } \\
\text { Stage }\end{array}$ & $\begin{array}{c}\text { DPPH } \\
\text { TE }(\mu \mathrm{mol} / \mathrm{g} \mathrm{DW})\end{array}$ & $\begin{array}{c}\text { FRAP } \\
\text { TE }(\mu \mathrm{mol} / \mathbf{g} \text { DW })\end{array}$ & $\begin{array}{c}\text { Superoxide Anion } \\
\text { IC }_{50}(\mathbf{g ~ D W})\end{array}$ \\
\hline Mature bud & $7.1 \pm 1.8 \mathrm{a}$ & $44 \pm 5 \mathrm{c}$ & $0.92 \pm 0.04 \mathrm{~b}$ \\
\hline Full bloom & $10.0 \pm 1.6 \mathrm{a}$ & $69 \pm 4 \mathrm{a}$ & $0.88 \pm 0.07 \mathrm{~b}$ \\
\hline Senescing & $7.1 \pm 1.6 \mathrm{a}$ & $57 \pm 4 \mathrm{~b}$ & $1.13 \pm 0.03 \mathrm{a}$ \\
\hline
\end{tabular}

In the same column, different letters correspond to statistically different means (Duncan's test, $n=3, p<0.05$ ).

\subsection{Volatile Organic Compounds Produced by Whole Flowers}

Figure 3 shows the GC/MS chromatogram of the volatile compounds emitted by the full bloom flowers of $P$. 'Endsleigh' indicating the presence of almost twenty chemical compounds, some of which remain unidentified. The chromatograms for the other stages of flower development do not differ significantly and are therefore not shown (Figures S2 and S3, while Table 5 summarises the list of identified compounds and their amounts in ng/g FW.

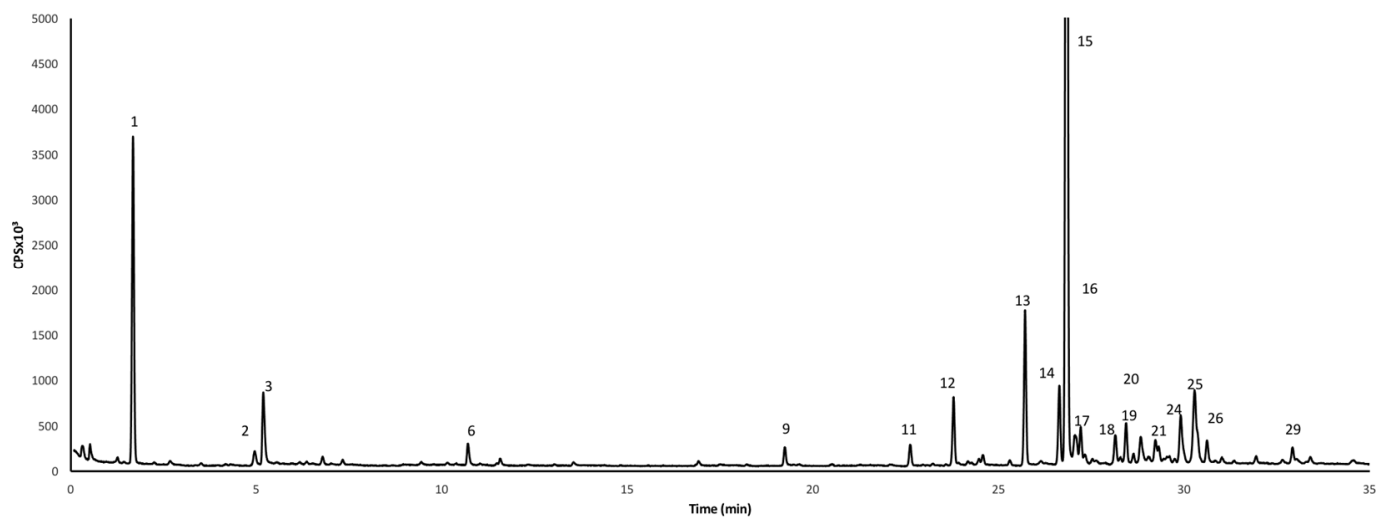

Figure 3. GC/MS chromatogram of VOCs emitted by full bloom flowers of P. ‘Endsleigh'. The peak numbers correspond to the compounds listed in Table 5.

The VOCs produced by $P$. 'Endsleigh' flowers at the three stages of flower development were estimated through a semi-quantitative procedure. Overall, VOCs decrease during flower development with values ranging from $444 \mathrm{ng} / \mathrm{g}$ to $184 \mathrm{ng} / \mathrm{g}$ FW (Table 5). In detail, almost all the compounds decrease from mature bud to senescing stages, except for 3-carene and two other unknown compounds which increase slightly while the ratios between the different compounds remain essentially similar. Among the various volatile compounds Guaia-6-9 diene is present in greater quantities, representing alone almost $50 \%$ of the identified VOCs; other compounds present in relatively high quantities are, in addition to the aforementioned 3-carene, $\alpha$-copaene, $\beta$-caryophyllene and Cadina-1(10),4-diene with amounts close to or greater than $20 \mathrm{ng} / \mathrm{g}$.

Table 5. Volatile organic compounds produced by $P$. 'Endsleigh' flowers at three different stages of development (mature bud, full bloom and senescing) and their semi-quantitative determination (ng/g FW).

\begin{tabular}{rrrrrr}
\hline \multirow{2}{*}{ No. } & RI & Compound Name & \multicolumn{2}{c}{ ng/g FW } \\
\cline { 4 - 7 } & 1011 & 3-Carene & $18.08 \pm 5.8$ & Full Bloom & Senescing \\
\hline 1 & 1035 & unknow & 0 & $2.26 \pm 1.9$ & $21.29 \pm 5.6$ \\
\hline 3 & 1038 & unknow & $3.85 \pm 1.5$ & $9.42 \pm 3.5$ & $3.52 \pm 2.5$ \\
\hline
\end{tabular}


Table 5. Cont.

\begin{tabular}{|c|c|c|c|c|c|}
\hline \multirow{2}{*}{ No. } & \multirow{2}{*}{ RI } & \multirow{2}{*}{ Compound Name } & \multicolumn{3}{|c|}{ ng/g FW } \\
\hline & & & Mature Bud & Full Bloom & Senescing \\
\hline 4 & 1040 & unknow & 0 & 0 & $1.14 \pm 0.6$ \\
\hline 5 & 1044 & $\beta$-Ocimene & 0 & 0 & $1.25 \pm 0.2$ \\
\hline 6 & 1114 & Fenchol & $4.87 \pm 1.7$ & $2.50 \pm 1.2$ & 0 \\
\hline 7 & 1228 & Ctronellol & 0 & 0 & $2.47 \pm 0.5$ \\
\hline 8 & 1250 & unknow & 0 & 0 & $0.86 \pm 0.3$ \\
\hline 9 & 1276 & 6-Octen-1-ol, 3,7-dimethyl-formate & $2.44 \pm 1.2$ & $2.09 \pm 1.4$ & $3.38 \pm 0.4$ \\
\hline 10 & 1310 & unknow & 0 & 0 & $1.1 \pm 0.5$ \\
\hline 11 & 1351 & $\alpha$-Cubebene & $3.87 \pm 1.3$ & $2.49 \pm 1.5$ & $1.41 \pm 1.4$ \\
\hline 12 & 1358 & $\alpha$-Copaene & $31.70 \pm 3.4$ & $7.97 \pm 1.4$ & $3.21 \pm 1.4$ \\
\hline 13 & 1420 & $\beta$-Caryophyllene & $28.53 \pm 3.7$ & $16.97 \pm 2.6$ & $8.21 \pm 1.4$ \\
\hline 14 & 1439 & $\alpha$-Guaiene & $13.89 \pm 1.4$ & $9.14 \pm 1.1$ & $4.93 \pm 1.0$ \\
\hline 15 & 1445 & Guaia-6-9 diene & $232.44 \pm 11.7$ & $169.98 \pm 21.7$ & $83.88 \pm 13.8$ \\
\hline 16 & 1451 & Aristolene & $7.85 \pm 2.1$ & $5.67 \pm 1.7$ & $1.27 \pm 1.2$ \\
\hline 17 & 1454 & Humulene & $7.00 \pm 1.3$ & $4.46 \pm 1.2$ & $1.60 \pm 0.5$ \\
\hline 18 & 1477 & $\gamma$-Himachalene & $4.96 \pm 1.4$ & $3.24 \pm 1.7$ & $0.95 \pm 0.3$ \\
\hline 19 & 1481 & Germacrene D & $11.24 \pm 1.9$ & $4.43 \pm 1.3$ & $2.87 \pm 1.8$ \\
\hline 20 & 1490 & $\beta$-Guaiene & $6.52 \pm 2.1$ & $3.69 \pm 1.4$ & $1.66 \pm 1.1$ \\
\hline 21 & 1494 & $\delta$-selinene & $7.11 \pm 1.3$ & $2.48 \pm 1.3$ & $1.66 \pm 1.2$ \\
\hline 22 & 1497 & $\alpha$-Muurolene & $4.53 \pm 1.4$ & 0 & $1.02 \pm 0.6$ \\
\hline 23 & 1502 & unknow & 0 & 0 & $10.11 \pm 1.7$ \\
\hline 24 & 1512 & unknow & $12.24 \pm 1.9$ & $7.45 \pm 1.7$ & $2.56 \pm 1.5$ \\
\hline 25 & 1519 & Cadina-1(10),4-diene & $21.49 \pm 3.5$ & $14.52 \pm 1.6$ & $6.49 \pm 1.9$ \\
\hline 26 & 1521 & unknow & $11.25 \pm 1.9$ & $2.91 \pm 1.1$ & $7.63 \pm 1.8$ \\
\hline 27 & 1529 & Citronellyl butyrate & $3.89 \pm 1.2$ & 0 & $3.32 \pm 1.7$ \\
\hline 28 & 1533 & unknow & $6.32 \pm 1.6$ & 0 & $5.91 \pm 1.4$ \\
\hline \multirow[t]{2}{*}{29} & 1542 & unknow & 0 & $2.66 \pm 1.2$ & $1.05 \pm 1.0$ \\
\hline & & Total amount & 444.07 & 309.10 & 184.75 \\
\hline
\end{tabular}

3.4. Volatile Organic Compoundsproduced by Sepals, Petals and Stamens/Pistils

Next, the odorous components were assessed in various parts of the P. 'Endsleigh' flower at full bloom: sepals, petals, anthers/pistils. The Figures 4-6 (showing the chromatograms of sepals, petals and anthers/pistils, respectively) clearly indicate that sepals are the main producers of volatile compounds. In fact, from Table 6 it can be seen that in sepals at full bloom all the VOCs are present in higher quantities (for $\mathrm{g}$ of FW) than in the whole flower. The compound present in greater quantities is again Guaia-6-9 diene with about $500 \mathrm{ng} / \mathrm{g} \mathrm{FW}$, followed by $\beta$-caryophyllene with approximately $100 \mathrm{ng} / \mathrm{g}$ FW. 


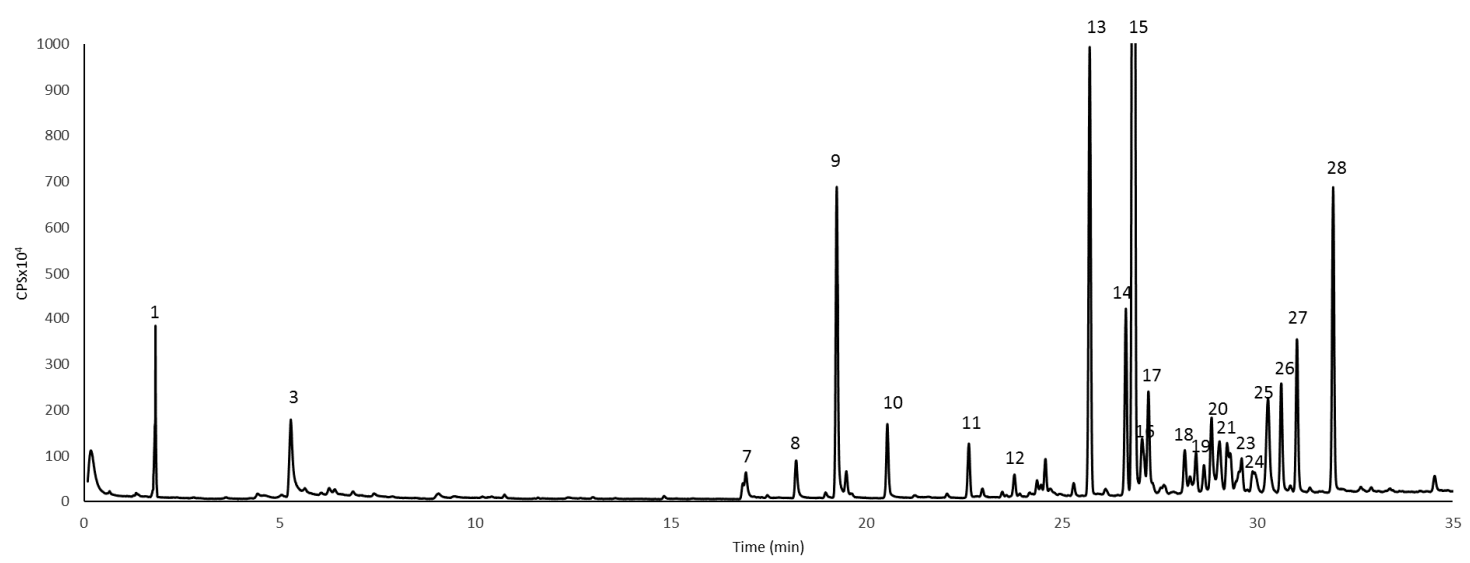

Figure 4. GC/MS chromatogram of $V O C$ s emitted by sepals of $P$. 'Endsleigh' flowers at full bloom. The peak numbers correspond to the compounds listed in Table 5.

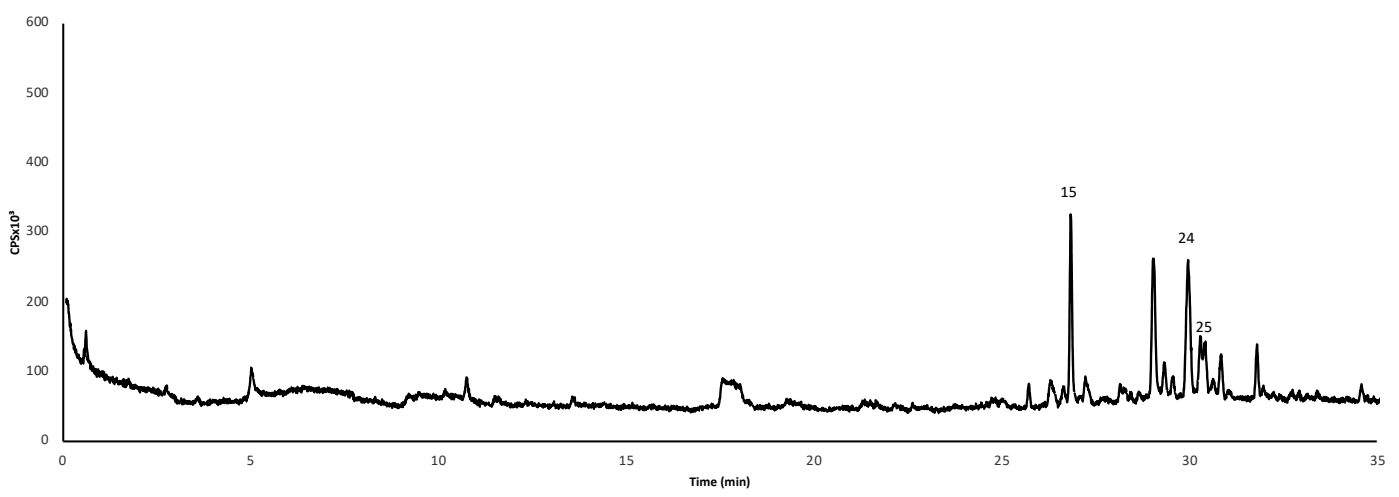

Figure 5. GC/MS chromatogram of VOCs emitted by petals of $P$. 'Endsleigh' flowers at full bloom. The peak numbers correspond to the compounds listed in Table 5.

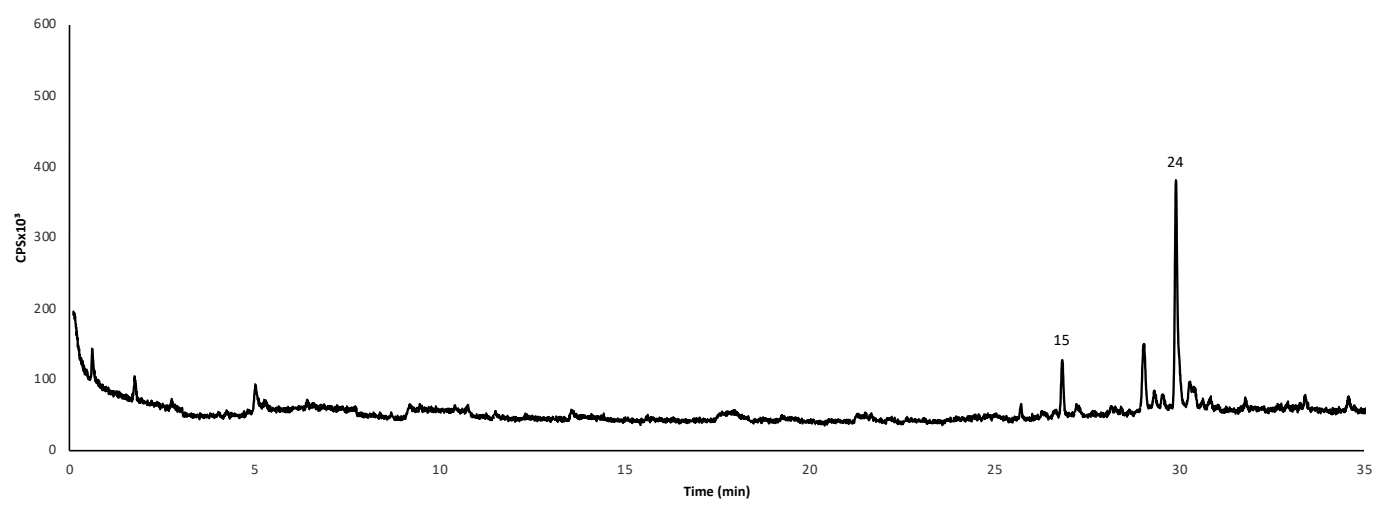

Figure 6. GC/MS chromatogram of VOCs emitted by anthers/pistils of $P$. 'Endsleigh' flowers at full bloom. The peak numbers correspond to the compounds listed in Table 5. 
Table 6. Volatile organic compounds produced by $P$. 'Endsleigh' sepals at full bloom and their semi-quantitative determination (ng/g FW).

\begin{tabular}{|c|c|c|c|}
\hline No. & R.I. & Compound Name & ng/g FW \\
\hline 1 & 1011 & 3-Carene & $75.19 \pm 12.3$ \\
\hline 3 & 1038 & unknow & $26.23 \pm 1.8$ \\
\hline 7 & 1228 & citronellol & $8.27 \pm 1.4$ \\
\hline 8 & 1250 & unknow & $10.2 \pm 1.2$ \\
\hline 9 & 1276 & 6-Octen-1-ol, 3,7-dimethyl-formate & $69.48 \pm 1.9$ \\
\hline 10 & 1310 & unknow & $23.73 \pm 2.7$ \\
\hline 11 & 1351 & $\alpha$-Cubebene & $11.99 \pm 2.2$ \\
\hline 12 & 1358 & $\alpha$-Copaene & $5.28 \pm 1.8$ \\
\hline 13 & 1420 & $\beta$-Caryophyllene & $97.69 \pm 7.3$ \\
\hline 14 & 1439 & $\alpha$-Guaiene & $41.37 \pm 5.2$ \\
\hline 15 & 1445 & Guaia-6-9 diene & $503.39 \pm 25.7$ \\
\hline 16 & 1451 & Aristolene & $18.51 \pm 2.5$ \\
\hline 17 & 1454 & Humulene & $26.16 \pm 2.7$ \\
\hline 18 & 1477 & $\gamma$-Himachalene & $10.86 \pm 5.2$ \\
\hline 19 & 1481 & Germacrene D & $10.44 \pm 3.7$ \\
\hline 20 & 1490 & $\beta$-Guaiene & $21.10 \pm 2.4$ \\
\hline 21 & 1494 & $\delta$-selinene & $9.24 \pm 2.2$ \\
\hline 23 & 1502 & unknow & $10.11 \pm 2.0$ \\
\hline 24 & 1512 & unknow & $10.23 \pm 2.1$ \\
\hline 25 & 1519 & Cadina-1(10),4-diene & $32.03 \pm 3.6$ \\
\hline 26 & 1521 & unknow & $24.70 \pm 4.1$ \\
\hline 27 & 1529 & Citronellyl butyrate & $32.47 \pm 5.3$ \\
\hline \multirow[t]{2}{*}{28} & 1533 & unknow & $65.41 \pm 7.1$ \\
\hline & & Total amount & 1045.16 \\
\hline
\end{tabular}

\section{Discussion}

A relatively low number of compounds have been detected in extracts obtained from the floral tissues of $P$. 'Endsleigh' flowers; we have identified approximately the same number of flavonoids as Boukhris et al. [28] in leaves and flowers of $P$. graveolens, but far fewer than the 40 compounds found by Marchioni et al. [29] in Pelargonium odoratissimum 'Lemon' or of over 50 compounds identified in the flowers of P. endliclerianum [30]. Few metabolites are in common with the flower of Geranium sylvaticum [22] but those shared kaempferol, quercetin and myricetin methyl ethers, are known to function as defensive compounds against herbivorous insects [31].

The level of total phenolic compounds was significant; the reported values are similar to those of flowers of P. odoratissimum [29] in which TPC content was the highest among the flowers of the four species analysed, and approximately $40 \%$ and $50 \%$ higher than that one of the flowers of Geranium sylvaticum [32] and P. graveolens flowers [28], respectively. Comparing with literature regarding edible flowers, the TPC content results $50 \%$ higher than the best of the 26 flowers analysed by Demasi et al. [33] and within the range of values reported by Janarny et al. [34] for Sri Lankan edible flowers.

The antioxidant activity, slightly higher at the stage of full bloom for $P$. 'Endsleigh', was not in accordance with the phenols content, but it was more or less in line with previous results $[28,33,34]$ despite the fact that authors use different units of measure. It would be 
advisable for all authors to express the values as a function of the original dry weight of the sample/plant organ.

There is very little work on the volatile compounds emitted by Geraniaceae flowers, hence it is only possible to compare data with Bozan et al. [30] (P. endliclerianum), Cao et al. [35] (P. hortorum), and Marchioni et al. [29] (P. odoratissimum). The major volatiles of P. endliclerianum flowers were Germacrene D (27.11\%), $\beta$-Caryophyllene $(11.34 \%)$, $\alpha$-Phellandrene $(9.79 \%), \alpha$-Pinene (4.89\%) [30]; for P. hortorum Zingiberene (29.88\%), $\alpha$-Longipinene (26.65\%), $\beta$-Myrcene (11.07\%) and 3-Hexen-1-ol (5.39\%) [35]; for the $P$. odoratissimum the two most present compounds were again Germacrene D $(27.03 \%)$ and $\beta$-Caryophyllene (23.23\%), followed in order by $(E)$ - $\beta$-Farnesene $(9.63 \%)$ and $\alpha$-Humulene (5.21\%) [29]. Table 5 shows instead the main volatiles of the $P$. 'Endsleigh' flowers at full bloom are different: the two major compounds are Guaia-6-9 diene (54.99\%), and 3-Carene $(11.25 \%)$, followed by $\beta$-Caryophyllene (5.49\%) and Cadina-1(10),4-diene (4.70\%), with Germacrene D only at $1.43 \%$. These data clearly indicate that the flowers of the different Pelargonium species produce both a remarkable variety of odour compounds and also varying combinations of the volatile compounds. In addition, the ratios between the various VOCs change slightly in the case of petals for which there is a greater presence of $\beta$-Caryophyllene than 3-Carene, 9.35\% compared with $7.19 \%$, respectively.

Then, in the case of $P$. 'Endsleigh' flowers the smells perceived by humans should be different from the other investigated Pelargonium flowers releasing mostly woody odours (sesquiterpenes with Guaiane Skeleton as Guaia-6-9 diene) [36], plus a sweet, turpentine/pine resin-like odour (3-Carene) [37], with a minor scent midway between odour of cloves and turpentine ( $\beta$-Caryophyllene) [37] and of thyme herbal woody dry (Cadina-1(10),4-diene) [38]. Anyway, of the major $P$. 'Endsleigh' flower VOCs only 3-Carene increase significantly during the flower development whereas $\alpha$-Copaene (woody spicy odour), which is the second most abundant VOC after Guaia-6-9 diene at mature bud stage falls in percentage terms from approximately $7 \%$ to less of $2 \%$ during the flower development (Table 5). In order to understand the meaning of these variations in VOCs production, it is necessary for the scientific community to produce more data regarding the ecological role of these chemical compounds to be included later in The Pherobase [39] which is already a useful reference. For instance, $\alpha$-copaene is a minor component but also a natural kairomone of Ceratitis capitata, a potent attractant for male of Mediterranean fruit flies [40] and it is produced by hundreds of flowers of different species [39].

In order to understand which floral organs produce VOCs, we have analysed sepals, petals and stamens / pistils separately. The result, compared to an identical fresh weight, was somewhat surprising as it was assumed that it was mainly the petals that emitted volatile compounds as e.g., the yield in phenols and flavonoids was higher in petals of Geranium sylvaticum [32]. On the contrary, as the scales of Figures 4-6 show, it is the sepals that produce a complex mixture of VOCs and in greater quantity than the other organs.

Previously, other authors have demonstrated that monoterpenes are emitted mostly from rose petals [41] and that peaking of floral fragrance in mature flowers enhances pollination efficiency [42,43]. In Rosa damascena, the main volatiles increase in the early stage flower development, peak in a second stage, decreasing thereafter [44]. Li et al. [45] for Luculia pinceana considered four stages of flower development (bud, initial-flowering, full-flowering and end-flower) showing that floral scent emission had its peak level at the initial-flowering stage; an identical result was obtained one year later by the same group for Luculia yunnanensis flowers [46]. In the case of tepals of Magnolia denudata the highest amount of volatiles and strongest aroma intensity are at the semi open stage [47]. Instead, Yu et al. [48] monitored volatile organic compounds emitted from Jasminum sambac 'Bifoliatum' flowers at five developmental stages (closed bud stage, start opening, opening, fully opened, start senescence) demonstrating a higher production of volatiles at flower opening. On the contrary, the flowers of the orchid Phalaenopsis bellina emit volatiles mainly at the stage of full bloom (3 stages: flower bud, partial bloom, full bloom) [49]; a similar result was also obtained by Bera et al. [50] for Zygopetalum maculatum. 


\section{Conclusions}

In conclusion, $P$. 'Endsleigh' flowers represent a good source of valuable VOCs and they could be suitable ingredients for new foods or cosmetics being rich in chemical compounds and antioxidant activities. Regardless, the presence of the different volatiles varies in relation to the flower development stage as the production of volatile compounds is maximum at mature bud stage and they are mainly emitted by sepals; the consequence of this regarding the use of edible flowers is that they should be harvested at the specific stage, taking care not to remove the flower organ most responsible for the production of volatile compounds.

Supplementary Materials: The following are available online at https:/ /www.mdpi.com/article/10 .3390 /horticulturae7110419/s1, Figure S1: HPLC/MS spectra of compounds identified; Figure S2: GC/MS chromatogram of VOCs emitted by mature bud flowers of $P$. 'Endsleigh'; Figure S3: GC/MS chromatogram of VOCs emitted by senescing flowers of $P$. 'Endsleigh'.

Author Contributions: Conceptualisation, C.N., R.D., L.D.B. and R.A.; methodology, C.N. and R.A.; formal analysis, C.N. and F.B.; investigation, C.N., R.D., S.M.A. and R.A; resources, L.D.B.; data curation, C.N. and A.L.; writing-original draft preparation, C.N., R.D., S.M.A. and A.M.; writingreview and editing: A.M., F.B. and L.D.B.; supervision, A.M., F.B. and L.D.B.; funding acquisition, A.L. and L.D.B. All authors have read and agreed to the published version of the manuscript.

Funding: This research was partially funded by Italian Ministry of Education, University and Research, Programma Operativo Nazionale FSE-FESR Ricerca e Innovazione 2014-2020, Asse I "Investimenti in Capitale Umano", Azione I.1 "Dottorati Innovativi con caratterizzazione industriale".

Institutional Review Board Statement: Not applicable.

Informed Consent Statement: Not applicable.

Data Availability Statement: All results are included within the article.

Conflicts of Interest: The authors declare no conflict of interest.

\section{References}

1. Eilers, E.J.; Kleine, S.; Eckert, S.; Waldherr, S.; Müller, C. Flower Production, Headspace Volatiles, Pollen Nutrients, and Florivory in Tanacetum vulgare Chemotypes. Front. Plant Sci. 2021, 11, 611877. [CrossRef]

2. Benvenuti, S.; Mazzoncini, M. The Biodiversity of Edible Flowers: Discovering New Tastes and New Health Benefits. Front. Plant Sci. 2021, 11, 569499. [CrossRef] [PubMed]

3. Demasi, S.; Mellano, M.G.; Falla, N.M.; Caser, M.; Scariot, V. Sensory Profile, Shelf Life, and Dynamics of Bioactive Compounds during Cold Storage of 17 Edible Flowers. Horticulturae 2021, 7, 166. [CrossRef]

4. The Herb Society of America. Pelargoniums: An Herb Society of America Guide. 2006. Available online: https://www. herbsociety.org/file_download/inline/2b2f9fc8-e827-446c-99da-1c1e8b6559d0 (accessed on 28 July 2021).

5. Deane, G. (2007-2012) Edible Flowers: Part Ten. Available online: http://www.eattheweeds.com/edible-flowers-part-ten/ (accessed on 15 September 2021).

6. Lauderdale, C.; Bradley, L. Choosing and Using Edible Flowers; North Carolina State University Extension: Raleigh, NC, USA, 2019; Available online: http:/ / content.ces.ncsu.edu/choosing-and-using-edible-flowers-ag-790 (accessed on 14 September 2021).

7. Lim, T.K. Edible Medicinal and Non Medicinal Plants, Volume 8, Flowers; Springer: Berlin/Heidelberg, Germany, 2014. [CrossRef]

8. Swain, R. Aromatic Pelargoniums. Arnoldia 1974, 34, 97-124. Available online: http:/ /www.jstor.org/stable/42962527 (accessed on 14 September 2021).

9. Just Geraniums. Available online: https://justgeraniums.weebly.com/store/p16/Scented_Plant_4_-_Pelargonium_Endsleigh_ Spice.html (accessed on 15 September 2021).

10. Pichersky, E.; Gershenzon, J. The formation and function of plant volatiles: Perfumes for pollinator attraction and defense. Curr. Opin. Plant Biol. 2002, 5, 237-243. [CrossRef]

11. Brückner, B. Consumer acceptance of fruit and vegetables: The role of flavour and other quality attributes. In Fruit and Vegetable Flavour: Recent Advances and Future Prospects, 1st ed.; Brückner, B., Wyllie, S.G., Eds.; Woodhead Publishing: Sawston, UK, 2008; pp. 11-17.

12. NIST. Computational Chemistry Comparison and Benchmark Database; NIST Standard Reference Database Number 101; Johnson, R.D., III, Ed.; NIST: Gaithersburg, MD, USA, 2015. [CrossRef]

13. Zhao, Y.; Li, Z.; Tian, W.; Fang, X.; Su, S.; Peng, W. Differential volatile organic compounds in royal jelly associated with different nectar plants. J. Int. Agric. 2016, 15, 1157-1165. [CrossRef] 
14. Negro, C.; Aprile, A.; De Bellis, L.; Miceli, A. Nutraceutical Properties of Mulberries Grown in Southern Italy (Apulia). Antioxidants 2019, 8, 223. [CrossRef]

15. Negro, C.; Sabella, E.; Nicolì, F.; Pierro, R.; Materazzi, A.; Panattoni, A.; Aprile, A.; Nutricati, E.; Vergine, M.; Miceli, A.; et al. Biochemical Changes in Leaves of Vitis vinifera cv. Sangiovese Infected by Bois Noir Phytoplasma. Pathogens $2020,9,269$. [CrossRef] [PubMed]

16. Oki, T.; Kobayashi, M.; Nakamura, T.; Okuyama, A.; Masuda, M.; Shiratusuchi, H.; Suda, I. Changes in radical-scavenging activity and components of mulberry fruit during maturation. J. Food Sci. 2006, 71, C18-C22. [CrossRef]

17. Benzie, I.F.F.; Strain, J.J. The ferric reducing ability of plasma as measure of "antioxidant power": The FRAP assay. Anal. Biochem. 1996, 239, 70-76. [CrossRef]

18. Beauchamp, C.; Fridovich, I. Superoxide dismutase: Improved assays and an assay applicable to acrylamide gels. Anal. Biochem. 1971, 44, 276-287. [CrossRef]

19. Mattivi, F.; Arapitsas, P.; Perenzoni, D.; Vrhovsek, U. L'analisi metabolomica descrive come cambia la composizione del vino durante la micro-ossigenazione, sotto l'effetto combinato di ossigeno e ferro. In La Ricerca Applicata ai Vini di Qualità; Di Blasi, S., Ed.; Firenze University Press: Florence, Italy, 2012; pp. 189-210.

20. Li, Y.; Ma, R.; Xu, Z.; Wang, J.; Chen, T.; Chen, F.; Wang, Z. Identification and quantification of anthocyanins in Kyoho grape juice-making pomace, Cabernet Sauvignon grape winemaking pomace and their fresh skin. J. Sci. Food Agric. 2013, 93, $1404-1411$. [CrossRef] [PubMed]

21. Ford, C.M. The biochemistry of organic acid in the grape. In The Biochemistry of the Grape Berry; Geros, H., Chaves, M.M., Delrot, S., Eds.; Bentham Science Publishers: Sharjah, United Arab Emirates, 2012; pp. 67-88.

22. Tuominen, A.; Toivonen, E.; Mutikainen, P.; Salminen, J.-P. Defensive strategies in Geranium sylvaticum, Part 1: Organ-specific distribution of watersoluble tannins, flavonoids and phenolic acids. Phytochemistry 2013, 95, 394-407. [CrossRef] [PubMed]

23. Al-Sayed, E.; Martiskainen, O.; Seif el-Din, S.H.; Sabra, A.-N.A.; Hammam, O.A.; El-Lakkany, N.M. Protective effect of Pelargonium graveolens against carbon tetrachloride-induced hepatotoxicity in mice and characterization of its bioactive constituents by HPLCPDA-ESI-MS/MS analysis. Med. Chem. Res. 2015, 24, 1438-1448. [CrossRef]

24. Jandrić, Z.; Frew, R.D.; Fernandez-Cedi, L.N.; Cannavan, A. An investigative study on discrimination of honey of various floral and geographical origins using UPLC-QToF MS and multivariate data analysis. Food Control 2017, 72, 189-197. [CrossRef]

25. Xie, Z.; Zhao, Y.; Chen, P.; Jing, P.; Yue, J.; Yu, L. Chromatographic Fingerprint Analysis and Rutin and Quercetin Compositions in the Leaf and Whole-Plant Samples of Di- and Tetraploid Gynostemma pentaphyllum. J. Agric. Food Chem. 2011, 59, 3042-3049. [CrossRef] [PubMed]

26. Wojdyło, A.; Nowicka, P.; Grimalt, M.; Legua, P.; Almansa, M.S.; Amorós, A.; Carbonell-Barrachina, Á.A.; Hernández, F. Polyphenol Compounds and Biological Activity of Caper (Capparis spinosa L.) Flowers Buds. Plants 2019, 8, 539. [CrossRef]

27. Afsheen, N.; Khalil-ur-Rehman; Jahan, N.; Ijaz, M.; Manzoor, A.; Khan, K.M.; Hina, S. Cardioprotective and Metabolomic Profiling of Selected Medicinal Plants against Oxidative Stress. Oxid. Med. Cell. Longev. 2018, 2018, 9819360. [CrossRef]

28. Boukhris, M.; Simmonds, M.S.J.; Sayadi, S.; Bouaziz, M. Chemical composition and biological activities of polar extracts and essential oil of rose-scented geranium, Pelargonium graveolens. Phytother. Res. 2013, 27, 1206-1213. [CrossRef]

29. Marchioni, I.; Pistelli, L.; Ferri, B.; Copetta, A.; Ruffoni, B.; Pistelli, L.; Najar, B. Phytonutritional Content and Aroma Profile Changes During Postharvest Storage of Edible Flowers. Front. Plant Sci. 2020, 11, 590968. [CrossRef]

30. Bozan, B.; Ozek, T.; Kurkcuoglu, M.; Kirimer, N.; Can Baser, K.H. The analysis of essential oil and headspace volatiles of the flowers of Pelargonium endlicherianum used as an anthelmintic in folk medicine. Planta Med. 1999, 65, 781-782. [CrossRef]

31. Harborne, J.B.; Williams, C.A. Phytochemistry of the genus Geranium. In Geranium and Pelargonium; Lis-Balchin, M., Ed.; Taylor \& Francis: London, UK, 2002; pp. 20-29.

32. Tuominen, A. Tannins and Other Polyphenols in Geranium sylvaticum: Identification, Intraplant Distribution and Biological Activity. Doctoral Thesis, University of Turku, Turku, Finland, December 2017. Available online: https://www.utupub.fi/ handle/10024/144333 (accessed on 15 September 2021).

33. Demasi, S.; Caser, M.; Donno, D.; Enri, S.R.; Lonati, M.; Scariot, V. Exploring wild edible flowers as a source of bioactive compounds: New perspectives in horticulture. Folia Hortic. 2021, 33, 27-48. [CrossRef]

34. Janarny, G.; Ranaweera, K.K.D.S.; Gunathilake, K.D.P.P. Antioxidant activities of hydro-methanolic extracts of Sri Lankan edible flowers. Biocatal. Agric. Biotechnol. 2021, 35, 102081. [CrossRef]

35. Cao, Y.; Li, C.; Yang, H.; Li, J.; Li, S.; Wang, Y.; Gao, Y. Laboratory and field investigation on the orientation of Frankliniella occidentalis (Thysanoptera: Thripidae) to more suitable host plants driven by volatiles and component analysis of volatiles. Pest Manag. Sci. 2019, 75, 598-606. [CrossRef] [PubMed]

36. Li, Z.; Howell, K.; Fang, Z.; Zhang, P. Sesquiterpenes in grapes and wines: Occurrence, biosynthesis, functionality, and influence of winemaking processes. Compr. Rev. Food Sci. Food Saf. 2020, 19, 247-281. [CrossRef]

37. PubChem. Available online: https:/ / pubchem.ncbi.nlm.nih.gov (accessed on 20 August 2021).

38. The Good Scents Company Information System. Available online: http:/ / www.thegoodscentscompany.com/index.html (accessed on 20 August 2021).

39. El-Sayed, A.M. The Pherobase: Database of Pheromones and Semiochemicals. 2021. Available online: https://www.pherobase. com (accessed on 20 August 2021). 
40. Nishida, R.; Shelly, T.E.; Whittier, T.S.; Kaneshiro, K.Y. $\alpha$-Copaene, a potential rendezvous cue for the Mediterranean fruit fly, Ceratitis capitata? J. Chem. Ecol. 2000, 26, 87-100. [CrossRef]

41. Guterman, I.; Shalit, M.; Menda, N.; Piestun, D.; Dafny-Yelin, M.; Shalev, G.; Weiss, D. Rose scent genomics approach to discovering novel floral fragrance-related genes. Plant Cell 2002, 14, 2325-2338. [CrossRef]

42. Dudareva, N.; Pichersky, E. Floral scent metabolic pathways: Their regulation and evolution. In Biology of Floral Scent; Dudareva, N., Pichersky, E., Eds.; CRC Press: Boca Raton, FL, USA, 2006; pp. 55-78. [CrossRef]

43. Parachnowitsch, A.L.; Raguso, R.A.; Kessler, A. Phenotypic selection to increase floral scent emission, but not flower size or colour in bee-pollinated Penstemon digitalis. New Phytol. 2012, 195, 667-675. [CrossRef]

44. Rasoulia, O.; Ahmadia, N.; Rashidi Monfared, S.; Sefidkon, F. Physiological, phytochemicals and molecular analysis of color and scent of different landraces of Rosa damascena during flower development stages. Sci. Hortic. 2018, 231, 144-150. [CrossRef]

45. Li, Y.; Ma, H.; Wan, Y.; Li, T.; Liu, X.; Sun, Z.; Li, Z. Volatile Organic Compounds Emissions from Luculia pinceana Flower and Its Changes at Different Stages of Flower Development. Molecules 2016, 21, 531. [CrossRef]

46. Li, Y.; Wan, Y.; Sun, Z.; Li, T.; Liu, X.; Ma, H.; Liu, X.; He, R.; Ma, Y.; Li, Z. Floral Scent Chemistry of Luculia yunnanensis (Rubiaceae), a Species Endemic to China with Sweetly Fragrant Flowers. Molecules 2017, 22, 879. [CrossRef] [PubMed]

47. Xiaoying, L.; JunKai, W.; Haijing, W.; Hongxia, Z.; Xuemin, G. Analysis of volatile components in whorl tepals of Magnolia denudata 'feihuang' during its development. Acta Hortic. Sin. 2019, 46, 2009-2020. [CrossRef]

48. Yu, Y.; Lyu, S.; Chen, D.; Lin, Y.; Chen, J.; Chen, G.; Ye, N. Volatiles Emitted at Different Flowering Stages of Jasminum sambac and Expression of Genes Related to $\alpha$-Farnesene Biosynthesis. Molecules 2017, 22, 546. [CrossRef] [PubMed]

49. Mus, A.A.; Gansau, J.A.; Kumar, V.S.; Rusdi, N.A. The variation of volatile compounds emitted from aromatic orchid (Phalaenopsis bellina) at different timing and flowering stages. Plant Omics 2020, 13, 78-85. [CrossRef]

50. Bera, P.; Chakrabarti, S.; Gaikwad, N.K.; Kutty, N.N.; Barman, M.; Mitra, A. Developmental variation in floral volatiles composition of a fragrant orchid Zygopetalum maculatum (Kunth) Garay. Nat. Prod. Res. 2019, 33, 435-438. [CrossRef] [PubMed] 